\title{
TŪRISMS KĀ IEDZĪVOTĀJU LABKLĀJĪBAS LĪMENI VEICINOŠS FAKTORS LATVIJAS PIEKRASTES PAŠVALDĪBĀS
}

\section{Daina Vinklere}

Biznesa augstskola Turība, e-pasts: Daina.Vinklere@turiba.Iv

\begin{abstract}
Anotācija. Latvijas piekrastes pašvaldībās tūrisma attīstībai pēdējos 25 gados tiek pievērsta liela uzman̄̄ba un ieguldīti līdzekḷi, lai kaut daḷēji kompensētu būtisko kritumu piekrastes rajoniem tradicionālajā zvejniecības un zivsaimniecības nozarēs ar mērḳi uzlabot iedzīvotāju labklājības līmeni un palēnināt iedzīvotāju migrāciju uz lielākajām pilsētām. Pētījumā analizēts, kā iedzīvotāji vērtē tūrisma
\end{abstract}


attīstības faktoru vietējo iedzīvotāju labklājības līmeṇa paaugstināšanā, izmantojot iedzīvotāju aptaujas izvēlētajās etalonteritorijās Kurzemes un Vidzemes piekrastē - Engures ezera sateces baseina un Salacgrīvas pašvaldībās, kurās ir līdzīga situācija resursu un attīstības ziņā. Pētījuma rezultāti parāda tendences iedzīvotāju vērtējumā, kas kopumā ir pozitīvākas Salacgrīvas pašvaldībā.

Atslēgas vārdi: iedz̄ivotāju labklājības līmenis, tūrisma sociāli-ekonomiskā ietekme reǵiona identitāte.

Labklājīibas jēdziens ir bijis aktuāls vienmēr, un katra valsts un pašvald̄̄iba ir ieinteresēta tās iespējami augstāka līmeņa nodrošināšanā. Terminiem labklājība un labklājības līmenis ir vairāki skaidrojumi, piemēram, "labklājība ir pārticība, turība, drošas nākotnes izredzes un veiksme saimnieciskos darījumos, tās priekšnosacījumi ir katras fiziskās personas rosība, labs darbs un čaklums, uzṇēmuma, valsts saimnieciskā attīstība, sociāli ekonomiskā stabilitāte u.c. (Ekonomikas skaidrojošā vārdnīca, 2000). Tiek lietots arī jēdziens sociālā labklājība, kas neapzīmē tikai dzīves līmeni, bet ietver arī dzīves kvalitāti un tādus tās faktorus kā vides kvalitāte, kriminogēnā situācija u.c.(Business Dictionary). Mēdz nošķirt arī t.s. subjektīvo labklājību, kas tiek definēta kā "pozitīvo emociju esamība un negatīvo neesamība, kā arī izzinošs dzīves vai dzīves vērtību kopuma novērtējums (Weismar, Ponocny 2015).

Tūrisma pētījumos labklājības aspekts nav plaši pētīts. Labklājību var skatīt gan no tūristu un tūrisma nozares, gan no vietējās sabiedrības skatu punkta (Hall, Brown 2006). Dažādos pētījumos un pārskatos tiek minēti dažādi rādītāji labklājības līmeņa novērtēšanai. Šajā gadījumā tiek izmantotas I. Jēkabsones piedāvātās objektīvo labklājības rādītāju grupas - iedzīvotāju skaita un sastāva pārmaiṇas, darba tirgus, uzņēmējdarbība un drošība (Jēkabsone 2014) iedzīvotāju subjektīvajā vērtējumā, kas parāda ar̄̄ vinu attieksmi pret tūrisma attīstību kopumā. Parasti šī attieksme saistās ar cilvēku personiskajiem ieguvumiem, kas rada pozit̄̄vu ietekmes uztveri un tālāku atbalstu tūrisma veicināšanai (Ap 1992).

Par piekrastes pašvaldībām Latvijā uzskata pašvaldības, kuru administratīvās teritorijas robežojas ar Baltijas jūru. Par tādām uzskatāmi 13 novadi un 4 republikas pilsētas - Rīga (23,5\% no teritorijas, kas atrodas 5 km zonā no krasta līnijas), Jūrmala, Liepāja un Ventspils. Šajās pašvaldībās dzīvo 45\% no visiem valsts iedzīvotājiem, no kuriem $\sim 10 \%$ novados, bet $\sim 90 \%$ republikas nozīmes pilsētās (Piekrastes telpiskās attīstības pamatnostādnes 2011.-2017. gadam).

Piekrastes reǵionu nozīmi tūrismā pierāda dati, ka Latvijā 2013. gadā 67\% tūrismā izmantoto gultasvietu atradās novados, kas ir pie jūras vai kam vismaz puse no teritorijas atrodas $10 \mathrm{~km}$ attālumā no jūras, bet $83,7 \%$ no kopējā apjoma veidoja pavadīto nakšu skaits piekrastes teritorijā. No šajā teritorijā esošajām mītnēm visvairāk viesnīcu un tām pielīdzināto mītņu atrodas Rīgā, Jūrmalā, Liepājā un Ventspilī (Tūrisma statistikas aktualitātes, CSB 2015). Šie rādītāji liecina par iedzīvotāju un tūrisma nozares augstu koncentrāciju lielajās pilsētās, kamēr piekrastes lauku teritorijās un mazpilsētās arvien vērojama iedzīvotāju skaita samazināšanās un arī ekstensīvāka tūrisma attīstība. Arī Eiropas Komisijas dokumentos tiek norādīts, ka galvenie šķēršlı Latvijas konkurētspējas un ekonomiskās, sociālās un teritoriālās kohēzijas attīstībā ir ievērojamas atškirīības 
starp lauku un pilsētu teritorijām, kur lauku teritorijās iedzīvotājiem ir lielāks nabadzības risks (European Commission 2014).

Tāpēc pētījuma mērkis bija noskaidrot tūrisma kā vietējo iedzīvotāju labklājību veicinoša faktora nozīmi divās izvēelētajās dažāda novietojuma, bet attīstības un resursu ziṇā līdzīgās etalonteritorijās ārpus republikas nozīmes pilsētām.

Engures ezera sateces baseins atrodas Kurzemes piekrastē, tā platība ir aptuveni 644 km² , bet galvenās vērtības - Engures ezera dabas parks, kā arī Baltijas jūras Rīgas līča piekraste. Šajā teritorijā ietilpst 5 novadu - Tukuma, Talsu, Mērsraga, Engures un Kandavas - un 11 pagastu teritoriju daļas. No tūrisma viedokḷa pētījuma teritorija iedalāma 3 atšķirīgās zonās gan pēc dabas un kultūrvēsturiskajiem resursiem, gan infrastruktūras, kas nosaka tūristu plūsmas intensitāti un attiecīgi arī tūrisma ietekmi (Rozīte, Vinklere 2011).

Salacgrīvas pašvaldība, atrodoties Ziemel,vidzemē pie Rīgas jūras līča, aizṇem 637 km² , un tajā ietilpst Salacgrīvas un Ainažu pilsēta ar lauku teritorijām un Liepupes pagasts. Arī šì novada galvenās vērtības rodamas dabas resursos. No tām tūrismam nozīmīgākās ir īpaši aizsargājamo dabas teritoriju sarakstā esošās Vidzemes akmeṇainā jūrmala, Randu plavas, Salacas upes ielejas posms, kā arī Rīgas jūras līča piekraste, kur arī koncentrējas galvenās tūristu plūsmas.

Abas etalonteritorijas ilgstoši bijušas atkarīgas no zvejniecības un zivsaimniecības attīstības, kas īpašu nozīmi ieguva padomju gados. Būtiski mainoties situācijai, pēdējos 20 gados visās piekrastes pašvaldībās, t.sk. šajās, par nozīmīgu alternatīvu tiek uzlūkota tūrisma attīstība, kas zināmā mērā var kompensēt zudušās darba vietas, līdzsvarot labklājības līmeni un tādējādi mazināt iedzīvotāju aizplūšanu uz pilsētām vai ārpus Latvijas.

Primāro datu iegūšanai tika izmantota iedzīvotāju aptauja. Engures ezera baseina teritorijas 12 apdzīvotās vietās tā veikta 2010.-2012. gadā Latvijas Nacionālā ilgtermiṇa ekoloğisko pētījumu tỉkla projektā „Konceptuālā modeḷa izveidošana socioekonomisko faktoru spiediena novērtēšanai uz biologisko daudzveidību ilgtermiņa pētījumu modeḷreǵionā Latvijā̄", savācot 387 derīgas anketas, bet Salacgrīvā 2014.-2015. gadā, iegūstot 400 derīgas anketas 5 apdzīvotās vietās. Iegūtais derīgo anketu skaits nodrošina izlases $95 \%$ ticamību ar $+/-5 \%$ robežkḷūdu (Kristapsone 2011). Ģenerālkopa Engures ezera sateces baseina teritorijā ietver noteiktu kḷūdu, jo tās robeža atšķiras no iekḷauto novadu un pagastu administratīvajām robežām.

Aptaujas anketā tika iekḷauti jautājumi, atbildes uz kuriem, izmantojot Likerta 5 ballu skalu, l̦auj spriest par iedzīvotāju subjektīvo vērtējumu kā labklājības līmeni ietekmējoša faktora nozīmei viṇu dzīvē, un iegūtie rezultāti apkopoti tabulā. 
Labklājības līmeni ietekmējošo tūrisma attīstību saistīto faktoru vērtējums Engures ezera sateces baseina (E) un Salacgrīvas pašvaldībās $(S)$ procentos no respondentu atbildēm

\begin{tabular}{|c|c|c|c|c|c|c|}
\hline Vērtējuma rādītāji & $\begin{array}{l}\text { Pilnībā } \\
\text { piekrītu } \\
\text { E/S }\end{array}$ & $\begin{array}{l}\text { Drīzāk } \\
\text { piekrītu } \\
\text { E/S }\end{array}$ & $\begin{array}{l}\text { Dal̄ēji } \\
\text { piekrītu } \\
\text { E/S }\end{array}$ & $\begin{array}{l}\text { Drīzāk } \\
\text { nepiekrīt } \\
\text { u } \\
\text { E/S }\end{array}$ & $\begin{array}{l}\text { Pilnībā } \\
\text { nepiekrīt } \\
\text { u } \\
\text { E/S }\end{array}$ & $\begin{array}{l}\mathrm{Nav} \\
\text { atbildes } \\
\mathrm{E} / \mathrm{S}\end{array}$ \\
\hline $\begin{array}{l}\text { Izjūtu, ka tūristi un atpūtnieki } \\
\text { dod ekonomisku labumu vietējai } \\
\text { sabiedrībai }\end{array}$ & $\begin{array}{l}14.5 / \\
68.0\end{array}$ & $\begin{array}{l}14.2 / \\
22.0\end{array}$ & $\begin{array}{l}14.7 / \\
6.0\end{array}$ & $\begin{array}{l}\text { 19.4/ } \\
3.0\end{array}$ & $\begin{array}{l}15.0 / \\
1.0\end{array}$ & $\begin{array}{l}22.2 / \\
0.0\end{array}$ \\
\hline $\begin{array}{l}\text { Tūristu un atpūtnieku piesaiste } \\
\text { rada papildus darba vietas } \\
\text { vietējiem }\end{array}$ & $\begin{array}{l}14.5 / \\
78.0\end{array}$ & $\begin{array}{l}15.0 / \\
14.0\end{array}$ & $\begin{array}{l}17.6 / \\
7.0\end{array}$ & $\begin{array}{l}15.8 / \\
1.0\end{array}$ & $\begin{array}{l}15.2 / \\
0.0\end{array}$ & $\begin{array}{l}22 / 2 \\
0.0\end{array}$ \\
\hline $\begin{array}{l}\text { Vietējie iedzīvotāji aktīvi } \\
\text { iesaistās maksas pakalpojumu } \\
\text { sniegšanā tūristiem un } \\
\text { atpūtniekiem }\end{array}$ & $\begin{array}{l}5.4 / \\
68.0\end{array}$ & $\begin{array}{l}10.3 / \\
21.0\end{array}$ & $\begin{array}{l}\mathbf{2 5 . 3 /} \\
5.0\end{array}$ & $\begin{array}{l}22.0 / \\
4.0\end{array}$ & $\begin{array}{l}14.7 / \\
2.0\end{array}$ & $\begin{array}{l}22.2 / \\
0.0\end{array}$ \\
\hline $\begin{array}{l}\text { Es vai mani ǵimenes locekḷi ( } \\
\text { bērni, vecāki, laulātie, brāḷi, } \\
\text { māsas) ir iesaistīti maksas } \\
\text { pakalpojumu sniegšanā } \\
\text { tūristiem/atpūtniekiem }\end{array}$ & $\begin{array}{l}7.0 / \\
10.0\end{array}$ & $\begin{array}{l}2.3 / \\
5.0\end{array}$ & $\begin{array}{l}6.7 / \\
13.0\end{array}$ & $\begin{array}{l}7.5 / \\
47.0\end{array}$ & $\begin{array}{l}\mathbf{5 4 . 3 /} \\
25.0\end{array}$ & $\begin{array}{l}22.2 / \\
0.0\end{array}$ \\
\hline $\begin{array}{l}\text { Tūristu skaita pieaugums ir } \\
\text { pozitīvi ietekmējis mūsu (vietējo } \\
\text { iedzīvotāju) dz̄̄ves līmeni }\end{array}$ & $\begin{array}{l}4.1 / \\
80.0\end{array}$ & $\begin{array}{l}11.6 / \\
10.0\end{array}$ & $\begin{array}{l}13.7 / \\
6.0\end{array}$ & $\begin{array}{l}14.7 / \\
3.0\end{array}$ & $\begin{array}{l}\text { 33.1/ } \\
1.0\end{array}$ & $\begin{array}{l}22.7 / \\
0.0\end{array}$ \\
\hline $\begin{array}{l}\text { Ceḷotāju/ tūristu piesaiste ir } \\
\text { nepieciešama mana dzīves līmeņa } \\
\text { uzlabošanai }\end{array}$ & $\begin{array}{l}11.6 / \\
17.0\end{array}$ & $\begin{array}{l}12.4 / \\
3.00\end{array}$ & $\begin{array}{l}21.7 / \\
60.0\end{array}$ & $\begin{array}{l}19.9 / \\
11.0\end{array}$ & $\begin{array}{l}12.4 / \\
9.00\end{array}$ & $\begin{array}{l}22.0 / \\
0.0\end{array}$ \\
\hline $\begin{array}{l}\text { Tūrisma veicināšanas pasākumi } \\
\text { palīdz uzlabot infrastruktūru, kas } \\
\text { vajadzīga arī vietējiem } \\
\text { iedzīvotājiem }\end{array}$ & $\begin{array}{l}20.2 / \\
59.0\end{array}$ & $\begin{array}{l}18.3 / \\
13.0\end{array}$ & $\begin{array}{l}16.5 / \\
6.0\end{array}$ & $\begin{array}{l}13.4 / \\
14.0\end{array}$ & $\begin{array}{l}8.5 / \\
8.0\end{array}$ & $\begin{array}{l}23.0 / \\
0.0\end{array}$ \\
\hline $\begin{array}{l}\text { Tūristu un atpūtnieku } \\
\text { pieplūduma rezultātā pasliktinās } \\
\text { kriminogēnā situācija }\end{array}$ & $\begin{array}{l}1.3 / \\
\mathbf{2 4 . 0}\end{array}$ & $\begin{array}{l}3.4 / \\
14.0\end{array}$ & $\begin{array}{l}6.2 / \\
19.0\end{array}$ & $\begin{array}{l}24.0 / \\
\mathbf{2 4 . 0}\end{array}$ & $\begin{array}{l}\mathbf{4 3 . 4 /} \\
19.0\end{array}$ & $\begin{array}{l}21.7 / \\
0.0\end{array}$ \\
\hline $\begin{array}{l}\text { Tūrisma attīstība ir veicinājusi } \\
\text { manu vai manas ǵimenes locekḷu } \\
\text { palikšanu/ pārcelšanos uz dzīvi } \\
\text { novadā }\end{array}$ & $\begin{array}{l}1.8 / \\
6.0\end{array}$ & $\begin{array}{l}1.6 / \\
7.0\end{array}$ & $\begin{array}{l}4.7 / \\
8.0\end{array}$ & $\begin{array}{l}10.9 / \\
39.0\end{array}$ & $\begin{array}{l}57.9 / \\
40.0\end{array}$ & $\begin{array}{l}23.3 / \\
0.0\end{array}$ \\
\hline $\begin{array}{l}\text { Pozitīvi izturos pret ienācējiem, } \\
\text { kas iegulda līdzekḷus un attīsta } \\
\text { tūristus apkalpojošus uzṇēmumus }\end{array}$ & $\begin{array}{l}11.6 / \\
63.0\end{array}$ & $\begin{array}{l}12.4 / \\
21.0\end{array}$ & $\begin{array}{l}21.7 / \\
8.0\end{array}$ & $\begin{array}{l}19.9 / \\
6.0\end{array}$ & $\begin{array}{l}12.4 / \\
2.0\end{array}$ & $22.0 / 0.0$ \\
\hline
\end{tabular}

Iepriekš analizētos Engures ezera sateces baseinā iegūtos rezultātus (Vinklere 2014) salīdzinot ar Salacgrīvas pašvaldībā iegūtajiem, redzam, ka daḷa faktoru ir vērtēti līdzīgi, tomēr vairākos ir būtiskas atšķirības. Attiecībā uz iespējamajiem migrāciju veicinošajiem faktoriem respondenti izteica atbalstu ienācējiem, kas ir pozitīvi attīstībai, bet abās vietās tūrisms kā motivētājs dzīvei novados tiek vērtēts visai zemu, īpaši Engures apkārtnē. Detalizētāk var spriest par respondentu vērtējumu saistībā ar darba 
tirgu un uzṇēmējdarbību. Respondentu viedoklis par jūtamu ekonomisko labumu, papildus darba vietām un iedzīvotāju aktivitāti ir būtiski augstāks Salacgrīvā, bet Engures baseinā tas tiek uzskatîts par maznozīmīgu, un abos gadījumos teju puse respondentu personīgi nav iesaistīti tūrisma pakalpojumu sniegšanā. Abas respondentu grupas augstu novērtē tūrisma lomu vietējiem nepieciešamās infrastruktūras uzlabošanā. Lai gan lielākā daļa respondentu atzīst, ka tūristu piesaiste ir nepieciešama viņu dzīves līmeņa uzlabošanai, tomēr kopumā, vērtējot tūristu pozitīvo ietekmi uz vietējo dz̄ives līmeni, ir diametrāli pretējs vērtējums, Salacgrīvā pozitīvajām atbildēm sasniedzot $~ 90 \%$, kamēr Engurē negatīvajām 50\%. Būtiski atšķirīgs vērtējums ir arī attiecībā uz drošības situāciju, kur Engures ezera apkārtnē to nesaskata kā draudu drošībai, kamēr Salacgrīvā viedoklis diezgan vienmērīgi sadalās un norāda uz noteiktām bažām, ko pašvaldībā būtu jāizvērtē.

Tādējādi pētījuma rezultāti ḷauj secināt, ka Salacgrīvas pašvaldības iedzīvotāji saskata būtiskāku ieguvumu no tūrisma viņu labklājības līmeņa paaugstināšanā, kas varētu būt saistīts gan ar plašāku piedāvājumu un intensīvāku tūristu plūsmu pa automaǵistrāli $\mathrm{A} 1$, gan administratīvo vienotību novadā, tomēr precīzāki iemesli būtu jāmeklē, turpinot pētījumu ar kvalitatīvo metožu pielietojumu.

\section{Atsauces}

Ap, J. (1992). Residents' perceptions on Tourism impacts. Annals of Tourism Research., 19, 665-690.

Business Dictionarry: http://www.businessdictionary.com/definition/socialwelfare.html\#ixzz3fU1CoGWi (17.02.2016)

European Commission. (2014) Latvia Partnership Agreement for 2014-2020.

Hall, D.R, Brown F. (2006). Tourism and Welfare: Ethics, Responsibility and Sustained Well-being, CABI, 239.

Jēkabsone, I., (2014). Objektīvās labklājības pētīšanas metodika. Prezentācija LU 72.zinātniskajā konferencē, Rīgā http://www.evf.lu.lv/fileadmin/user_upload/lu_portal/ projekti/evf/konferences/lu72konference/publiskas_parvlades/Jekabsone.pdf (15.02.2016)

Kristapsone, S. (2011). Izlase un tās veidošanas metodes. Ievads pētniecībā: stratēǵijas, dizaini, metodes. Rīga: Raka

Rozīte, M., Vinklere, D. (2011). Tourism and recreation as a driving force for forecasting biodiversity changes: Lake Engure. Watershed area as an example. Proceedings of the Latvian Academy of Sciences, 5/6, 192-197.

Tūrisma statistikas aktualitātes. Informatīvais pārskats. http://www.csb.gov.lv/sites/ default/files/nr_31_turisma_statistikas_aktualitates_15_00_lv.pdf (01.02.2016)

Vides aizsardzības un regiionālās attīstības ministrija (2011). Piekrastes telpiskās attīstības pamatnostādnes 2011. - 2017. gadam.

Vinklere, D. (2014) Tūrisma nozīme un ietekme iedzīvotāju vērtējumā: Engures ezera sateces baseina pašvaldību piemērs. Daugavpils universitātes 56. Starptautiskās zinātniskās konferences rakstu krājums, akadēmiskais apgāds "Saule", Daugavpils, 64-71.

Weismayer, C., Ponocny, I. (2015). The relationship between leisure resource information and regional well-beeing: a GIS approach. European Journal of Tourism, Hospitality and recreation,6-1, 75-102. 


\section{Summary}

Over the past 25 years heightened attention and resources has been accorded to coastal municipalities for tourism development in Latvia with its almost $500 \mathrm{~km}$ long coastline in order to partly compensate to some extent the significant decrease in the traditional fishing and fish processing industries in the coastal regions and improve the welfare level of inhabitants and slow down their migration to the bigger cities. The study analyses the evaluation of local inhabitants of tourism development as a factor enhancing the inhabitants' level of welfare of based on a survey carried out in the sample areas on the Kurzeme and Vidzeme coasts - Engure watershed area and Salacgriva municipalities which are similar in terms of resources and development level. The research results reveal similarities and differences in the inhabitants' evaluation, which on the whole are more positive for the Salacgriva municipality area. 